\title{
SUCCESSFUL CONTROL PROGRAM TO IMPLEMENT THE APPROPRIATE ANTIBIOTIC PROPHYLAXIS FOR CESAREAN SECTION
}

\author{
Silvia Nunes Szente FONSECA(1), Maria Helena SOFIA(1), Silvana QUINTANA(1), Fernanda dos Santos NOGUEIRA(1) \& Anna S. LEVIN(2)
}

\begin{abstract}
SUMMARY
Objective: Describe implementation of a successful program to reduce doses (cefazolin 2 to $1 \mathrm{~g}$ ) used for antimicrobial prophylaxis. Methods: Evaluation of an intervention program to reduce prophylactic antimicrobial doses. The intervention included weekly staff discussions, automatic dispensation of $1 \mathrm{~g}$-vial of cefazolin by the pharmacy unless expressly requested by surgeon and increase in post-discharge surveillance as a strategy to reassure surgeons of the safety of the reduction. In the pre and post intervention periods, a prospective study of antimicrobial consumption and surgical site infections were measured. Results: There were 5,164 and 5,204 deliveries in 2001-2002 and 2003-2004, respectively; 1,524 (29.5\%) and 1,363 (26\%) were cesarean sections. There was a $45 \%$ decrease in cefazolin vials used on average per cesarean section (2.29 to 1.25). Patients evaluated increased from $16 \%$ to $67 \%$ and the SSI rates in both periods were $3.34 \%$ to $2.42 \%$, respectively. Conclusion: An ample intervention, including administrative and educational measures, led to high compliance with dose reduction and saved more than US $\$ 4,000$ in cefazolin, considered important because government reimbursement in Brazil for cesarean section is $\$ 80$.
\end{abstract}

KEYWORDS: Antimicrobial prophylaxis; Cesarean section; Compliance; Cefazolin; Surgical site infection.

Major postoperative infectious complications such as endometritis and surgical site infection are important causes of maternal morbidity ${ }^{10}$. Antibiotic prophylaxis is recommended in order to decrease infectious complications in high risk cesarean sections ${ }^{1,2,26}$. In 1990, EHRENKRANZ et al. ${ }^{10}$ demonstrated that routine timely antibiotic prophylaxis might be associated with a $70 \%$ to $75 \%$ reduction of risk of either endometritis or wound infection in low-risk cesarean sections. CHELMOW et al. ${ }^{8}$ confirmed these findings in a meta-analysis demonstrating that prophylactic antibiotic use in low-risk cesarean sections was associated with a significant reduction in postoperative fever and endometritis. More recently, in a cost-analysis study this same group ${ }^{7}$ concluded that administration of prophylactic antibiotics for elective cesarean delivery reduced costs by US\$30.66 per case resulting in cost savings for elective cesarean delivery. Most clinical guidelines ${ }^{2,9,11,13,23,27}$ advocate the use of a single dose of 1 to $2 \mathrm{~g}$ of cefazolin right after the clamping of the cord in cesarean deliveries. Increasing healthcare costs have led (or forced) hospitals and clinics to review procedures, in order to adjust their budgets. Also, concerns with antimicrobial resistance have pressured infection control specialists to decrease antimicrobial usage. There is a variation of dosage of cefazolin in the randomized controlled trials and both 1 and 2 grams are doses suggested in guidelines. To achieve the aim of the most cost effectiveness under limited resources, a single dose of 1 gram administered immediately after cord clamping among women undergoing cesarean section is the most appropriate. Despite the established evidence on the safety of prophylaxis guidelines in cesarean sections doctors do not change practices easily and compliance with single-dose prophylaxis for example has been reported to be only 8 to $22 \%{ }^{19,20}$. Based upon a previously successful experience of implementation of a protocol involving single $2 \mathrm{~g}$ dose for prophylaxis ${ }^{12}$, we decided to decrease the dosage of prophylactic cefazolin from 2 grams to 1 gram in cesarean sections because less use of antibiotics could bring considerable savings for our philanthropic institution. Although well established for years, guidelines on the use of prophylactic antimicrobial are very often not followed ${ }^{6}$. In our hospital, house staff physicians were very concerned that this modification would increase surgical site infections (SSI) despite published recommendations supporting the use of 1 gram of cefazolin ${ }^{1,23,27}$. The objective of this study was to describe a successful program to reduce doses and costs of antimicrobial prophylaxis without increasing cesarean section SSI rates.

\section{METHODS}

Mater is a philanthropic hospital for women located in Ribeirão Preto, Brazil. It runs on a limited budget and cares for low-income women. Mater is supported in part (40\% of expenses) by the Brazilian National Health System; the majority of expenses are paid by a non-profit foundation, Maternidade Sinhá Junqueira Foundation. Mater receives preferentially low-risk patients; high-risk patients are transferred to a 


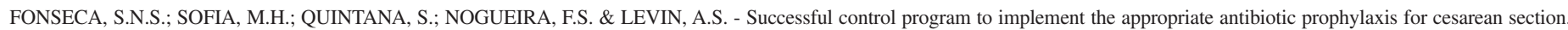
Rev. Inst. Med. trop. S. Paulo, 50(2): 79-82, 2008.

University-affiliated hospital. Fifty percent of Mater patients earn less than US\$100/month, $20 \%$ are illiterate, $52 \%$ did not complete eight years of education, $36 \%$ are having their first baby and $18 \%$ are teenagers. Brazil is well known for its high rate of elective cesarean procedures ${ }^{4,5}$ but in Mater indications for cesarean procedures follow the current established National and International guidelines ${ }^{21,24}$ acute fetal distress, severe preeclampsia and HELLP syndrome, dystocia, congenital anomalies, malpresentation, two or more previous cesarean sections; and these indications did not change over the study period. In-hospital surveillance (IHS) was started in the year 2000; also patients were encouraged to come back for a check-up in Mater if any abnormality developed after hospital discharge. The Centers for Disease Control and Prevention definitions for nosocomial infections were used ${ }^{15}$.

In 2003, to obtain the evidence-based practice under the limited resources, as in our hospital, we changed the recommended dosage of cefazolin used for SSI prevention in cesarean sections from $2 \mathrm{~g}$ to $1 \mathrm{~g}$ right after the clamping and cutting of the umbilical cord in all women undergoing cesarean sections. Before this control program was implemented, intensive discussions took place in weekly meetings during two months. These meetings involved chief obstetritians, nurses, administration staff and infection control personnel. During these meetings all the strategies, difficulties and cost implications of the new protocol were discussed. The clinical director, himself an anesthesist, was present and supported the new policy. It was decided by all, that the pharmacy would automatically dispense only one $1 \mathrm{~g}$-vial of cefazolin unless expressly requested, in writing by the patient's surgeon, to do otherwise, and that any changes would be reported to the infection control department. In our hospital cefazolin is a restricted drug and is used only for cesarean section prophylaxis. Adherence to the protocol was measured by comparing the number of used cefazolin vials starting in 2001 through 2004. We estimated compliance by calculating the average prophylaxis dose per cesarean section, by dividing the total number of used 1-gram vials by the number of cesarean sections performed in each period. The $1 \mathrm{~g}$-cefazolin vial costs US $\$ 2.50$; we calculated the costs with cefazolin by multiplying the number of vials by this value. No other modification in the standard procedures besides dosage reduction was implemented in 2003, and the medical staff did not change. We compared results from two different periods: January 2001 to December 2002 and January 2003 to December 2004. To assure the staff, especially the surgeons, that the dose reduction was safe, we also compared SSI rates diagnosed during the first 30 days after delivery, and reinforced measures to increase active post-discharge active surveillance. An outpatient clinic to evaluate infection in patients after discharge was initiated as part of the intervention measures. Post-discharge surveillance (PDS) was done scheduling regular patient appointments with nurses for discharged patients approximately two weeks after delivery, looking for surgical site infections (SSI) (superficial, deep and endometritis) and urinary tract infections (UTI). The patients were asked to return if there were any other problems after this visit.

The costs with cefazolin in both periods were also evaluated. The study was approved by the Ethics Committee of the Hospital.

\section{RESULTS}

The main results can be seen in Table 1. The total number of deliveries remained stable in both study periods; the proportion of cesarean sections was significantly reduced from $29.5 \%$ in $2001-2$ to $26 \%$ in 2003-4 $(p<0.001)$. The number and proportion of contacted patients by post-discharge surveillance (PDS) however increased significantly (from $16 \%$ to $67 \%$ ) in 2003-2004 due to an increased effort of the nursing staff to schedule patients for their return visits after delivery. SSI rates nevertheless did not change. The rate of endometritis remained stable in both periods. There were less urinary tract infections in 2003-2004 although not statistically significant. There was almost a $50 \%$ decline in the annual number of cefazolin vials purchased (from 3,487 to 1,702 and a lower mean number of cefazolin vials per cesarean section (2.52 to 1.25$)$, with corresponding savings of more than US $\$ 4,000$ with the purchase of cefazolin alone.

Table 1

Total number of deliveries; proportion of cesarean sections; rates of infection; and number and costs of cephazolin vials purchased in 2001-2002 and 2003-2004

\begin{tabular}{lll}
\hline & $2001-2002$ & $2003-2004$ \\
\hline \# Deliveries & 5,164 & 5,204 \\
\# C-sections (\%) & $1,524(29.5 \%)$ & $1,363(26 \%)$ \\
\# Contacted patients (\%) & $808(16 \%)$ & $3,487(67 \%)$ \\
\# Total SSI C-sections (\%) & $51(3.34 \%)$ & $33(2.42 \%)$ \\
\# Superficial SSI (\%) & $26(1.7 \%)$ & $21(1.54 \%)$ \\
\# Deep SSI (\%) & $7(0.46 \%)$ & $2(0.15 \%)$ \\
\# C-section endometritis (\%) & $18(1.18 \%)$ & $9(0.66 \%)$ \\
\# C-section UTI (\%) & $13(0.85 \%)$ & $6(0.44 \%)$ \\
\# Cephazolin vials (costs in US\$) & $3,487(\$ 8,717)$ & $1,702(\$ 4,255)$ \\
\# Cephazolin vials/C-section & 2.29 & 1.25 \\
\hline
\end{tabular}

C-section = cesarean section; $\mathrm{SSI}=$ surgical site infection; UTI $=$ urinary tract infection.

\section{DISCUSSION}

The implementation of a control program for an appropriate regimen of antibiotic prophylaxis in cesarean section, as the recommended in our study, was successful. Before the control program was launched, comprehensive education and intensive discussion among the stakeholders were positively responded. Not only the cost of cefazolin but also the gap of evidence-based practice on antibiotic prophylaxis in cesarean section was reduced.

Preceding the implementation of the new protocol, extensive education on the new policy was done allowing ample discussion among all the staff involved. We also took administrative measures to make proper prophylaxis practically automatic and required surgeons to expressly request, in writing, any prescription that did not follow the protocol. The almost $50 \%$ decrease in cefazolin vial use also pleased the administrators who played a very important role in actively supporting the policy and making sure that only 1-g cefazolin vials would be dispensed from pharmacy.

Infection is described as an important complication of surgery and is a costly complication of cesarean deliveries ${ }^{7,10}$. Antimicrobial prophylaxis is one of the preventive strategies used to decrease infectious complications; on the other hand, inappropriate and indiscriminate use of prophylactic antibiotics may increase costs through unnecessary drug 
use. Several guidelines have been published ${ }^{2,26}$ suggesting that a single dose of cefazolin right after the clamping of the cord is effective for SSI prevention but the recommended dosage varies between 1 and 2 grams. We saw in these recommendations an opportunity to safely decrease antibiotic usage in our institution by decreasing prophylaxis in cesarean section from $2 \mathrm{~g}$ to $1 \mathrm{~g}$ of cefazolin. Costs are an appealing argument for decreasing antibiotic usage; there are publications in the literature showing substantial savings with less antibiotic usage ${ }^{3,12,25}$. Our data pointed to a yearly decrease in costs of more than US $\$ 2,000$ considering only the decrease in the purchase of cefazolin vials. Although this decrease may be viewed as modest it was considered important because the Brazilian National Health System reimbursement for a cesarean section is only US\$80.

It is a well known fact that SSI is much more common in cesarean deliveries than in normal deliveries ${ }^{16,18}$. HEMSELL ${ }^{13}$ in a literature review, showed that low socioeconomic status, young maternal age, long duration of membrane rupture and preoperative anemia are risk factors for SSI after cesarean deliveries, and all these are common features in our population. More recently, KILLIAN et al. ${ }^{17}$ showed, in a multivariate analysis of over 700 patients undergoing cesarean deliveries, demonstrated that the risk of SSI increased 2.58 fold in the absence of prophylaxis $\left(\mathrm{CI}_{95 \%}, 1.3-5.1\right)$. Although there are well established guidelines for prophylaxis in surgical procedures, compliance has been reported to be relatively low. In one report involving different surgical procedures, the moment of starting the antimicrobial was correct in less than $60 \%$, and discontinuation was adequate in $41 \%$ of the operations ${ }^{6}$.

The reasons given for non-compliance with guidelines or hospital recommendations were: the personal experience of the physician; difficulty or a perceived contamination during the operation; the belief that multiple doses are superior to one under their local conditions ${ }^{13}$. One of the main concerns of our house staff was the possible increase in the rates of infection in our low-income population. Therefore we considered it essential to implement surveillance of infectious complications to assure the staff that the infection rates would not increase. SSI rates are better determined through post-discharge surveillance. Most SSIs will occur after the patient is discharged ${ }^{14,22}$. In maternity ward where patient length of stay is always very short it is probable that almost all infectious complications will go undetected ${ }^{17}$ unless a post-discharge surveillance system is implemented. We implemented such a system, and we increased the proportion of contacted patients from $16 \%$ to $67 \%$ from 2001-2002 to 2003-2004. To our surprise, the SSI rates in 2003-2004 did not increase. For the house staff, these data were very reassuring.

Our study has limitations. First, we performed an observational study in which there was no simultaneous control group. We did not evaluate each patient submitted to a cesarean delivery to assess if both groups of patients were comparable. Because no substantial modification of the general patient population (low-income and low risk young patients) occurred from 2001 to 2004, and because of the large number of patients studied, we believe that no such bias occurred. Second, no attempt was made to assess if prophylaxis was correctly given right after cord clamping. It is our understanding that it is very important to assess and ensure correct timing. Another limitation is that each patient could not be evaluated individually as to compliance to the new dose. However we feel that compliance could be adequately estimated based on average consumption of cefazolin per cesarean section, as this drug was restricted and used only for this indication.

We believe that it is a difficult task to achieve compliance with surgical prophylaxis protocols. To succeed it is necessary to implement educational and administrative measures and to deal with the beliefs of the surgeons concerning safety for the patients.

\section{RESUMO}

\section{Sucesso de um programa para a implantação de profilaxia antimicrobiana apropriada em cesárea}

Objetivo: descrever a implantação de um programa de redução de doses usadas para profilaxia antimicrobiana em cesárea. Métodos: Descrição a implantação de um programa de redução de profilaxia com cefazolina de $2 \mathrm{~g}$ para $1 \mathrm{~g}$ através de discussões semanais com profissionais, dispensação automática de frascos de $1 \mathrm{~g}$ de cefazolina pela farmácia exceto quando feito pedido expresso pelo cirurgião. Houve um trabalho para aumentar a vigilância pós alta, com o objetivo de tranquilizar os cirurgiões quanto à segurança da nova dose. Foi realizada uma avaliação prospectiva, antes e depois da implantação do programa, do consumo de cefazolina e das taxas de infecção obtidas por vigilância durante a hospitalização e após a alta. Resultados: Houve 5.164 e 5.204 partos em 2001-2 e 2003-4, respectivamente, sendo que $1.524(29,5 \%)$ e $1.363(26 \%)$ foram cesáreas. Houve uma queda de consumo de frascos de cefazolina de $45 \%$ (2,29 para 1,25 por cesárea). O número de pacientes avaliados para infecção hospitalar aumentou de $16 \%$ para $67 \%$, e as taxas de infecção foram $3,34 \%$ e $2,42 \%$, respectivamente. Conclusão: Uma intervenção ampla, que incluiu medidas administrativas e educacionais, levou a uma alta adesão ao programa de redução de dose profilática em cesárea e permitiu uma economia acima de US\$ 4.000 apenas considerando custos com cefazolina. Esta pode ser considerada importante especialmente porque o reembolso do SUS para parto cesárea é aproximadamente US\$ 80.

\section{ACKNOWLEDGMENT}

This work was supported by the Maternidade Sinhá Junqueira Foundation.

\section{REFERENCES}

1. ANONYMOUS - Antibiotic prophylaxis in surgery: a national clinical guideline. Scottish Intercollegiate Guideline Network (SIGN), 45: 1-49, 2000.

2. ANONYMOUS - Antimicrobial prophylaxis in surgery. In: ABRAMOWICZ, M., ed The medical Letter on Drugs and Therapeutics, 43: W1116-W1117, 2001.

3. BANTAR, C.; SARTORI, B.; VESCO, E. et al. - A hospitalwide intervention program to optimize the quality of antibiotic use: impact on prescribing practice, antibiotic consumption, cost savings, and bacterial resistance. Clin. infect. Dis., 37: 180-186, 2003.

4. BARROS, F.C.; VAUGHAN, J.P.; VICTORA, C.G. \& HUTTLY, S.R. - Epidemic of cesarean sections in Brazil. Lancet, 338: 167-169, 1991.

5. BELIZAN, J.; ALTHABE, F.; BARROS, F. \& ALEZANDER, S. - Rates and implications of cesarean sections in Latin America: ecological study. Brit. med. J., 319: 13971400, 1999. 


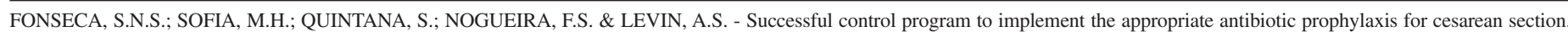
Rev. Inst. Med. trop. S. Paulo, 50(2): 79-82, 2008.

6. BRATZLER, D.W.; HOUCK, P.M.; RICHARDS, C. et al. - Use of antimicrobial prophylaxis for major surgery-baseline results from the National Surgical Infection Prevention Project. Arch. Surg., 140: 174-182, 2005.

7. CHELMOW, D.; HENNESY, M. \& EVANTASH, E.G. - Prophylactic antibiotics for non-laboring patients with intact membranes undergoing cesarean delivery: an economic analysis. Amer. J. Obstet. Gynec., 191: 1661-1665, 2004.

8. CHELMOW, D.; RUEHLI, M.S. \& HUANG, E. - Prophylactic use of antibiotics for nonlaboring patients undergoing cesarean delivery with intact membranes: a metaanalysis. Amer. J. Obstet. Gynec., 184: 656-661, 2001.

9. DELLINGER, E.P.; GROSS, P.A.; BARRETT, T.L. et al. - Quality standard for antimicrobial prophylaxis in surgical procedures. The Infectious Diseases Society of America. Infect. Control Hosp. Epidem., 15: 182-188, 1994.

10. EHRENKRANZ, N.J.; BLACKWELDER, W.C.; PLAFF, S.J. et al. - Infections complicating low-risk cesarean sections in community hospitals: efficacy of antimicrobial prophylaxis. Amer. J. Obstet. Gynec., 162: 337-343, 1990.

11. EHRENKRANZ, N.J. - Antimicrobial prophylaxis in surgery: mechanisms, misconceptions, and mischief. Infect. Control Hosp. Epidem., 14: 99-106, 1993.

12. FONSECA, S.N.S.; KUNZLE, S.R.M.; SILVA, S.A.B.; SCHMIDT Jr., J.G. \& MELE, R.R. - Cost reduction with successful implementation of an antibiotic prophylaxis program in a private hospital in Ribeirão Preto, Brazil. Infect. Control Hosp. Epidem., 20: 77-79, 1999.

13. HEMSELL, D.L. - Prophylactic antibiotics in gynecologic and obstetric surgery. Rev. infect. Dis., 13 (suppl. 10): S821-S841, 1991.

14. HOLTZ, T.H. \& WENZEL, R.P. - Postdischarge surveillance for nosocomial wound infection: a brief review and commentary. Amer. J. Infect. Control, 20: 206-213, 1992.

15. HORAN, T.C.; GAYNES, R.P.; MARTONE, W.J.; JARVIS, W.R. \& EMORI, T.G. - CDC definitions of nosocomial surgical site infections, 1992: a modification of CDC definitions of surgical wound infections. Infect. Control Hosp. Epidem., 13: 606$608,1992$.

16. KANKURI, E.; KURKI, T.; CARLSON, P. \& HIILESMAA, V. - Incidence, treatment and outcome of peripartum sepsis. Acta obstet. gynec. scand., 82: 730-735, 2003.

17. KILLIAN, C.A.; GRAFFUNDER, E.M.; VINCIGUERRA, T.J. \& VENEZIA, R.A. Risk factors for surgical-site infections following cesarean section. Infect. Control Hosp. Epidem., 22: 613-617, 2001.
18. KOROUKIAN, S.M. - Relative risk of postpartum complications in the Ohio Medicaid population: vaginal versus cesarean delivery. Med. Care Res. Rev., 61: 203-224, 2004

19. LIABSUETRAKUL, T. \& ISLAM, M. - Evidence on antibiotic prophylaxis for cesarean section alone is not sufficient to change the practices of doctors in a teaching hospital. J. Obstet. Gynaec. Res., 31: 202-209, 2005

20. LiABSUETRAKUL, T.; LUMBIGANON, P. \& CHONGSUVIVATWONG, V. Prophylactic antibiotic prescription for cesarean section. Int. J. Qual. Hlth Care, 14: 503-508, 2002

21. LIU, S.; RUSEN, I.D.; JOSEPH, K.S. et al. - Recent trends in caesarean delivery rates and indications for cesarean delivery in Canada. J. Obstet. Gynaec. Res., 26: 735 $742,2004$.

22. McClAVE, T.J. \& DIETRICH, F.H. - Statistics. San Francisco, Dellen Publishing Company, 1985

23. MINER, A.L.; SANDS, K.E.; YOKOE, D.S. et al. - Enhanced identification of postoperative infections among outpatients. Emerg. infect. Dis., 10: 1931-1937, 2004

24. PAGE, C.P.; BOHNEN, J.M.; FLETCHER, J.R. et al. - Antimicrobial prophylaxis for surgical wounds. Guidelines for clinical care. Arch. Surg., 128: 79-88, 1993.

25. PEREIRA, P.P. \& ZUGAIB, M. - A cesariana. A polêmica nas indicações; a técnica na atualidade; a profilaxia das infecções. In: CAMANO, L., ed. Manual de orientação FEBRASGO: assistência ao parto e tocurgia. São Paulo, Editora Porto, 2002. p. 101-119.

26. SAIZY-CALLAERT, S.; CAUSSE, R.; FURHMAN, C. et al. - Impact of a multidisciplinary approach to the control of antibiotic prescription in a general hospital. J. Hosp. Infect., 53: 177-182, 2003.

27. SMAILL, F. \& HOFMEYR, G.J. - Antibiotic prophylaxis for cesarean section (Cochrane Review), 2004. Chichester, John Wiley, 2004. (The Cochrane Library, Issue 4).

Received: 9 August 2007

Accepted: 14 December 2007 